\title{
Natural Coating from VG2S in Reducing Surface Temperature.
}

\author{
AHZ Abidin ${ }^{1}$, RC Omar ${ }^{2}$, R Roslan ${ }^{3}$, Hairin Taha ${ }^{4}, K_{\text {K Sanusi }}^{5}$. \\ ${ }^{1}$ College of Graduates Study \\ ${ }^{2,3,4}$ Institute of Energy Infrastructure \\ ${ }^{5}$ Tenaga Nasional Berhad \\ Universiti Tenaga Nasional, 43000, Kajang, Malaysia. \\ *Corresponding Author E-mail: aminahannazaidin@yahoo.com
}

\begin{abstract}
Urban heat island (UHI) is a condition where urban area experiences increase in temperature than rural area caused by the affect from the modification of land surfaces. In urban areas, roads are one of the main elements that contribute to UHI as roads are mostly paved with dark pavement. When pavements become hotter, the excess heat is radiated back into the atmosphere resulting in a higher surrounding temperature than those in rural areas. The objective of this study is to develop a new coating material for pavers from VG2S that can reduce surface heat. Two methods were used in this study, immersed and layered methods for comparing standard paver with new innovated paver with VG2S coating. FLIR thermal imaging camera and infrared thermometer gun are used for measuring surface heat. The surface heat result shows reduction in surface temperature by $5^{\circ} \mathrm{C}$ to $10^{\circ} \mathrm{C}$ compared to uncoated standard sample and white paint color pave sample (control) which are slightly lower by $1^{\circ} \mathrm{C}$ to $2^{\circ} \mathrm{C}$ from coating sample. The studies demonstrated that VG2S coating can be applied as cool coatings and contribute to a significant reduction of the cooling demand in warm climates.
\end{abstract}

Keywords: coating, pavement, surface heat, UHI, vege-grout.

\section{Introduction}

As urban areas develop, changes occur in the landscape where open land covered with low natural vegetation are being replaced by buildings, roads and other infrastructures for improving our lives, comfort and needs [1]. Because of this development, urban heat island (UHI) occurs when the condition of the urban area or cities experience increase in higher ambient temperature than that of the rural area. This will indirectly affect the indoor temperature of urban building that required more energy consumption to cool the building. Besides that, higher temperature in the city can affect the health of people $[2,3]$. Urban surface materials have low reflectivity and they will absorb and reserved heat during the day. Subsequently the stored heat will be released at night time and this will increase the temperature of the surroundings [4]. Pavements (e.g., roads, pedestrian walkways) are one of the main hardscapes contributing to the UHI effect. The pavements in urban area, absorbs heat on sunny day, and become more hotter compare to the ambient canopy temperature and will radiated the heat to the atmosphere at night time, resulting in a higher ambient temperature than those in rural areas $[5,6]$.

The technology of cool pavement is one of the ways to mitigate urban heat islands as it absorbs less heat and subsequently this will decrease the surface temperature [7]. Previous studies showed that many techniques in the making of cool pavement have been developed to reduce the surface heat temperature through mixture of variety of materials that consists of reflective material, vegetation cover, photovoltaic pavement, and waste tile $[7,8,9$, 10]. However, this method is not adaptable to existing roads or pedestrian walkways because this will involve the construction of new pavement that can be costly and laborious. Therefore, it would be practical to developed cool coating to be applied on the existing pavements as another alternative option to reduce surface heat that contribute to UHI. There are several cool coatings that have been developed such as condensation resins (polyvinyl alcohol and epoxy resin), silica, tile aggregates, and dark-pigment color coating but none of them were obtained from natural materials $[11,12,13,14]$. For this study, a new coating material will be developed from vege-grout or vegetable waste extract based on Microbial Induced Calcite Precipitation (MICP). The natural coating will be developed from the bio-cementation process that will create the coating layer.

The vege-grout contains ureolytic microorganism which precipitate the calcite or calcium carbonate $\left(\mathrm{CaCO}_{3}\right)$ from the calcium irons in the vege-grout through some chemical reaction $[15,16]$. Previous studies reported on the application of microorganism to improve the soil strength and the permeability of soil as this technique has very low carbon footprint $[17,18,19]$. It is also proven that this technique is very economical and environmental friendly as it can solve problem in disposal of vegetable waste [20]. As there are many studies on bio-grout material for soil improvement to alter the mechanical properties of liquefied soil, there has yet any study conducted on vege-grout to investigate its effectiveness in reducing surface heat temperature. Therefore, this study is an extension of vege-grout application in the related geo-engineering field.

\section{Materials and Methods}

The aim of this study is to develop a new material of coating for existing pavement to mitigate its surface temperature. Thus, in this study, a new natural coating material will be developed from vege-grout and its effectiveness in reducing surface temperature of pavers will be analyzed. The first step is to prepare a VG2S 
extract and then to develop natural coating from the substance. After that, the natural coating will be applied on pavers for testing and its surface temperature was then recorded.

\subsection{Preparation of Vege-Grout}

Vege-grout or VG2S is a substance made from vegetable waste. The recycle vegetables include cucumber, water spinach, spinach, long bean and cabbage. Each of them was weighed $10 \mathrm{~kg}$, washed to avoid any impurities, cut into pieces and stored in container for 30 days to undergo fermentation process. After 30 days, it was then filtered to get the liquid which is called vege-grout or VG2S. This procedure of vege-grout preparation is shown in the Figure 1 below.

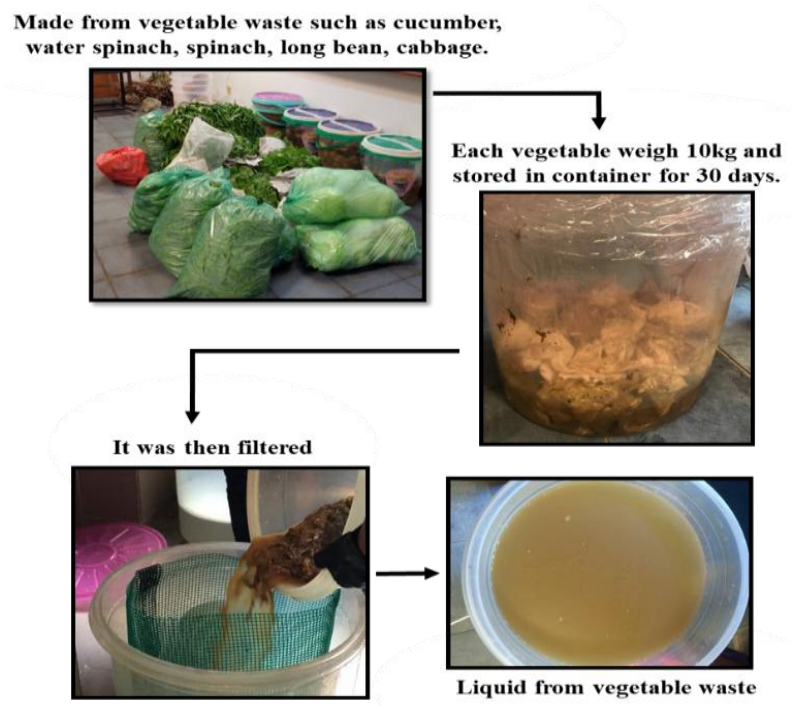

Fig. 1: Procedure of vege-grout preparation.

\subsection{Development of Natural Coating}

Natural coating was developed form vege-grout called VG2S coating with eggshell, white paint made by clay process and urea that are synthesis from ball clay. Figure 2 shows the development coating process to form VG2S coating. Eggshell [21] was used to provided calcium element $(\mathrm{Ca})$ to give a medium for anaerobic bacteria to enhance their activities in the process of biocementation. Urea was added to induced the process of urea hydrolysis by ureolytic microorganism in the vege-grout [22].

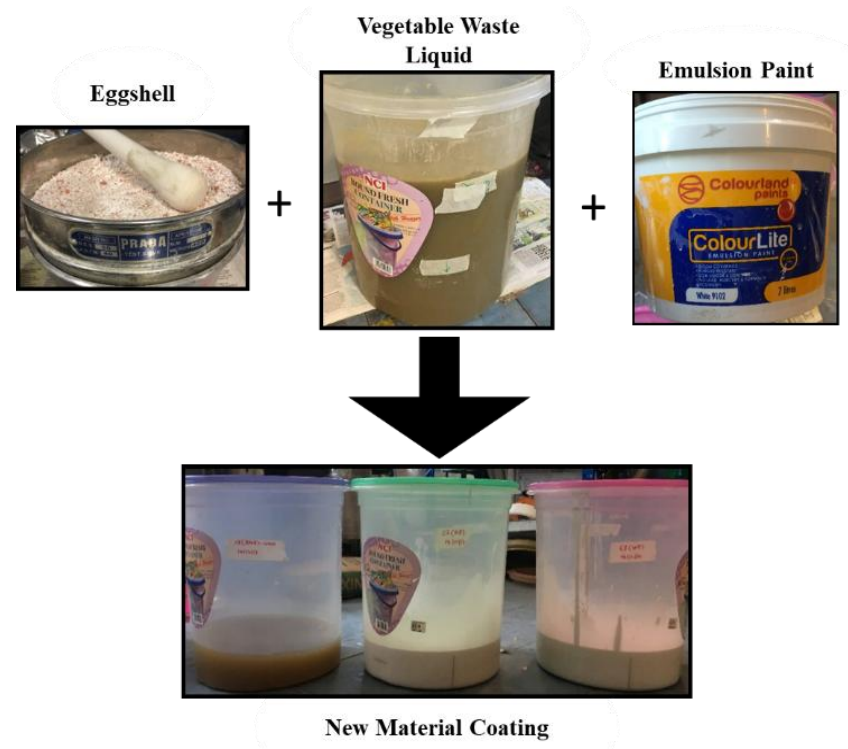

Fig. 2: Materials used in the study.

\subsection{Experimental Details}

The standard red color interlocking pavers were used in this study. The surface heat of standard pavement is between $\left(40^{\circ} \mathrm{C}\right.$ to $\left.60^{\circ} \mathrm{C}\right)$. Due to that, the red color interlocking pavers are chosen. Two methods used in this study name as layered method and immersed method. For layered method, vege-grout coating was applied on paver by using brush and for immersed method, pavers were submerged in the vege-grout coating for 24 hours and all samples were compared to control samples (negative control-uncoated paver, positive control-white coated paver). After that, samples were dried out in the sun for 8 hours and this process was carried out for 2 weeks. Figure 3 shows on how experiment on paver was set up while for Figure 4 show on how methods applied on paver were carried out. After drying process was completed, surface temperature of the samples was measured and recorded using LCD Laser Infrared Digital Temperature Thermometer Gun as shown in Figure 5 and also thermal infrared image of samples were taken by thermal imaging camera. All data were taken at $9 \mathrm{am}, 12 \mathrm{pm}$ and $3 \mathrm{pm}$ for 7 days.
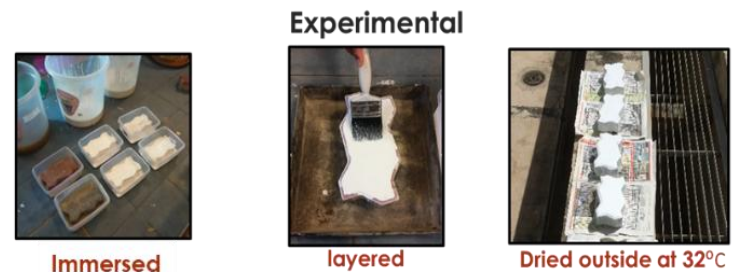

Immersed

layered

Dried outside at $32^{\circ} \mathrm{C}$
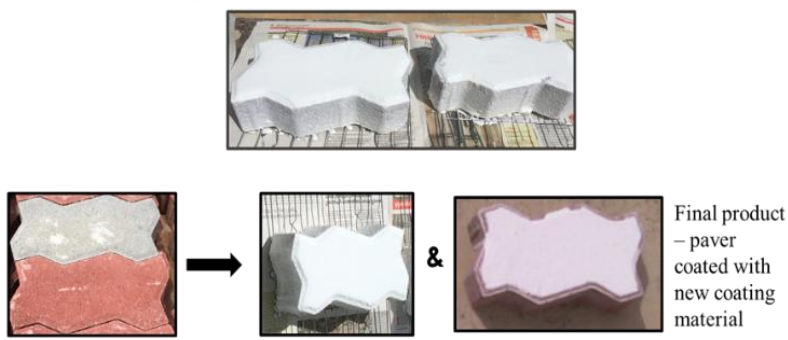

Fig. 3: Experimental setup.

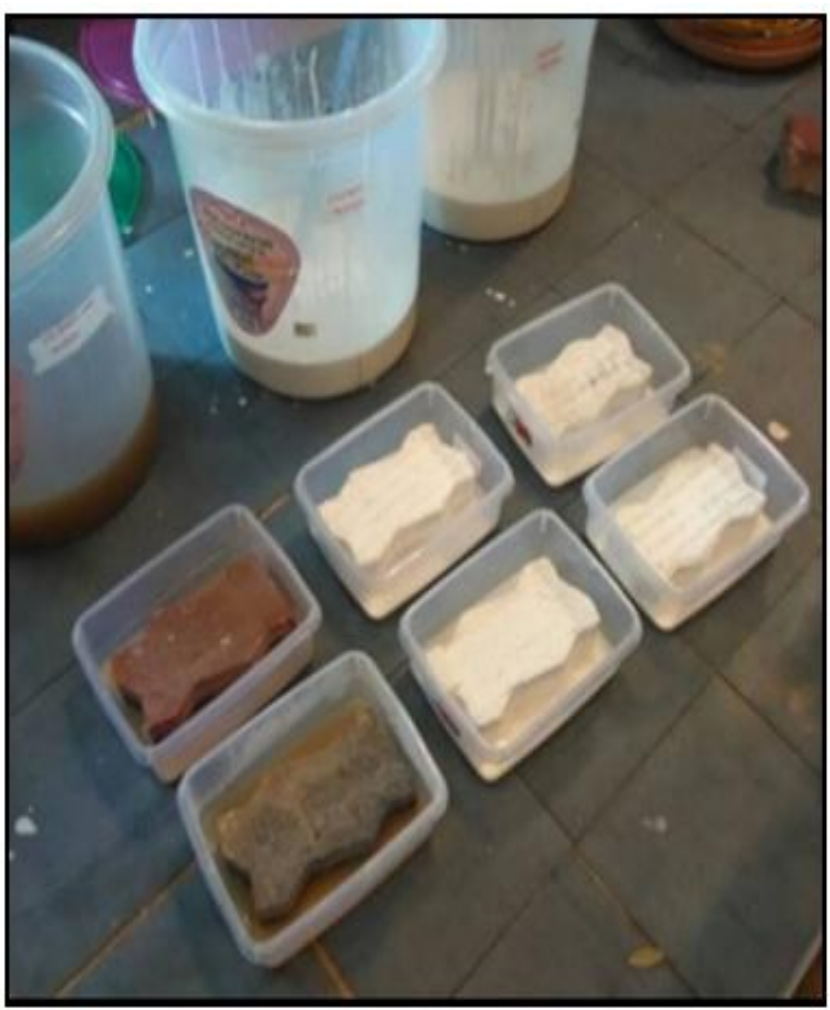

Fig. 4: Pavers were submerged in coatings in immersed method 


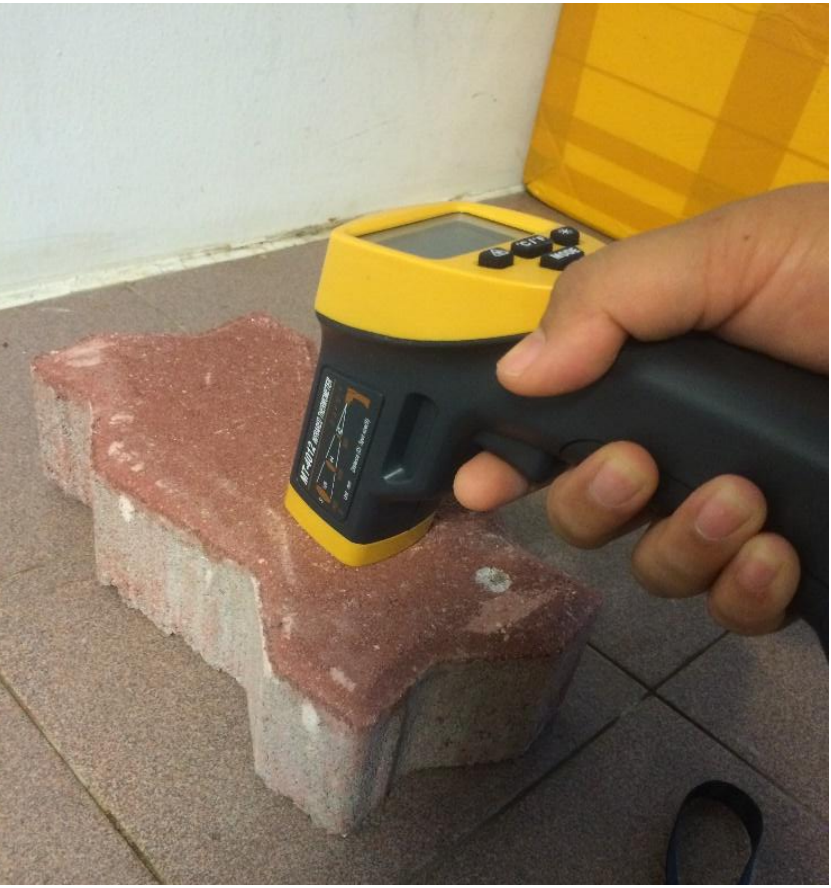

Fig. 5: Surface temperature recorded by using LCD Laser Infrared Digital Temperature Thermometer Gun.

\section{Results}

Discussion in this section will based on collection experimental result from surface temperature, thermal image and Scanning Electron Micrograph (SEM-EDX) analysis.

\subsection{Surface Temperature}

Data of surface temperature in this experiment were recorded using LCD Laser Infrared Digital Temperature Thermometer Gun. Data were taken during day at 9am, 12pm, and 3pm for a week period. Control samples have the highest temperature recorded among the samples. Temperature of samples is shown in the table below. Average ambient temperature recorded was $32^{\circ} \mathrm{C}$. It was sunny and bright day and there is no drastic change in temperature. Therefore, all data recorded of all samples were discussed as average temperature of samples. Data from $12 \mathrm{pm}$ were critically discussed as there was big difference on surface temperature between samples.

Table 1: Average Surface Temperature of Samples.

\begin{tabular}{|c|c|c|c|c|c|}
\hline \multirow{2}{*}{ Time } & \multicolumn{7}{|c|}{ Table 1: Average Surface Temperature of Samples. } \\
\cline { 2 - 6 } & $\begin{array}{c}\text { C3 } \\
\text { (Negati } \\
\text { ve } \\
\text { control } \\
\text { ) }\end{array}$ & $\begin{array}{c}\text { Sample } \\
\text { (Positive control, } \\
\text { Immerse) }\end{array}$ & $\begin{array}{c}\text { B2 } \\
\text { (Vege- } \\
\text { grout } \\
\text { coating } \\
\text { C6 } \\
\text { Immer } \\
\text { se) }\end{array}$ & $\begin{array}{c}\text { Cositi } \\
\text { ve } \\
\text { contro } \\
\text { Layere } \\
\text { d) }\end{array}$ & $\begin{array}{c}\text { B4 } \\
\text { (Vege- } \\
\text { grout } \\
\text { coatin } \\
\text { g, } \\
\text { Layere } \\
\text { d) }\end{array}$ \\
\hline $\begin{array}{c}9: 00 \\
\text { am }\end{array}$ & 21.9 & 21.3 & 21.2 & 21.4 & 21.2 \\
\hline $\begin{array}{c}12: 00 \\
\text { pm }\end{array}$ & 35.3 & 32.2 & 31.1 & 32.2 & 30 \\
\hline $\begin{array}{c}3: 00 \\
\text { pm }\end{array}$ & 33.8 & 31.8 & 30.9 & 31.9 & 31 \\
\hline
\end{tabular}

Below is the graph of average surface temperature of experimental interlocking pavers. In immerse method, negative control sample has the highest temperature followed by positive control sample, and VG2S coating sample. From the graph, it can be seen clearly that there are $4.2^{\circ} \mathrm{C}$ of differences in surface temperature between negative control samples and VG2S coating. While differences of surface temperature between positive control sample and VG2S coating sample is $1.1^{\circ} \mathrm{C}$. The same pattern of temperature sequences from immersed method also occurred in layered method Negative control sample has the highest surface temperature followed by positive control sample and lastly VG2S coating sample. There are $2.2^{\circ} \mathrm{C}$ differences of surface temperature between positive control sample and vege-grout coating sample. As for negative control sample and VG2S coating sample, the differences of their surface temperature are $5.3^{\circ} \mathrm{C}$.

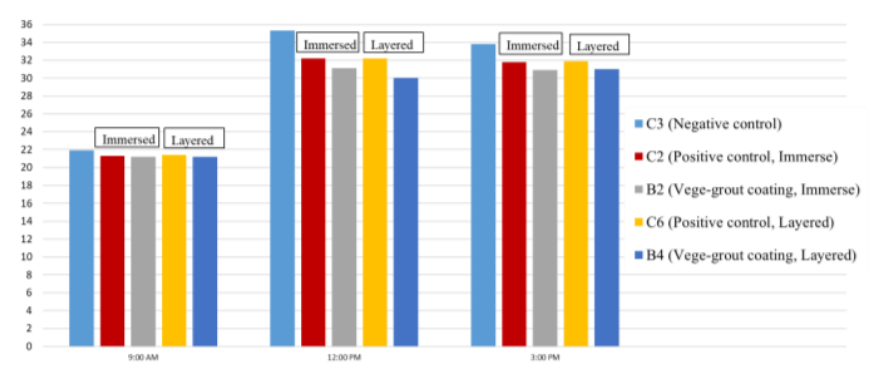

Fig. 6: Graph of average surface temperature of experimental paver.

From previous study, there is cool coating that has been developed from silica [13] however the differences of surface temperature between cool coatings and control sample only $3^{\circ} \mathrm{C}$ to $2.5^{\circ} \mathrm{C}$. VG2S coating reaches a higher differences of surface temperature compare to the results of previous study that is $5.3^{\circ} \mathrm{C}$. This result shows that VG2S can helps the material to reduce the surface temperature of interlocking paver.

\subsection{Thermal Infrared Images}

Thermal infrared images of samples were taken by FLIR thermal imaging camera. These images were taken at the same time with surface temperature data were recorded. As there was no drastic changes in ambient temperature during experiment were carried out, data on day 3 were discussed. This is because the ambient temperature during that day slightly higher than other days with only 1 to $2^{\circ} \mathrm{C}$ differences.

Figure 7, 8 and 9 are the thermal images of samples between VG2S coating (A2) and positive control (C2) of immersed method. Figure 7 was taken at $9 \mathrm{am}$ and the surface temperature differences between samples were $1{ }^{\circ} \mathrm{C}$. This is because the ambient temperature during morning is still cool. At $12 \mathrm{pm}$ the differences of surface temperature become bigger that is $1.6^{\circ} \mathrm{C}$ as shown in Figure 8. As for Figure 9, image was taken at $3 \mathrm{pm}$ and its differences of surface temperature is $1.7^{\circ} \mathrm{C}$.

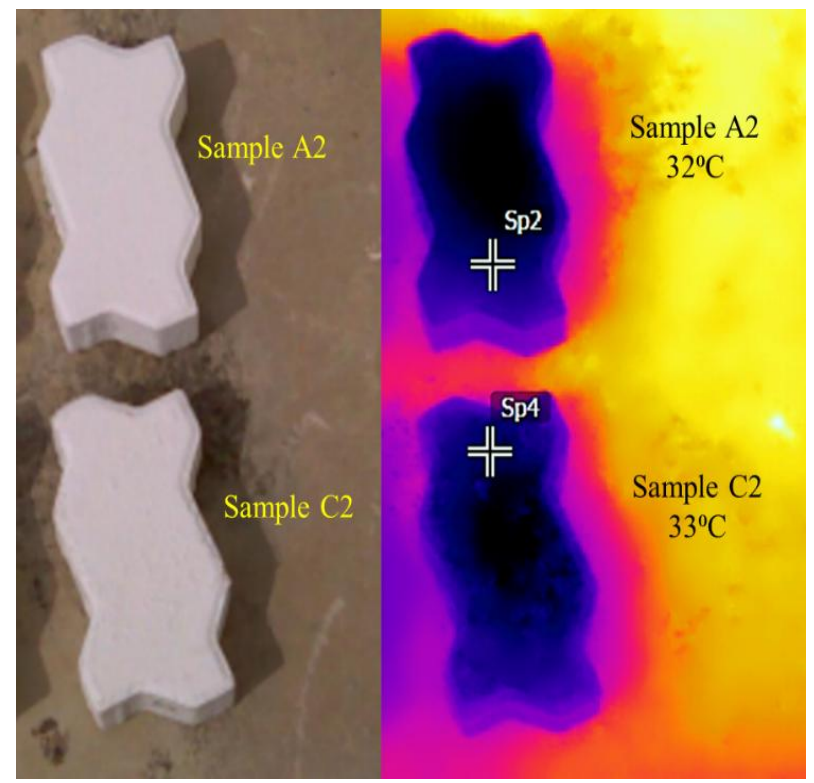

Fig. 7: Thermal images of vege-grout coating and positive control sample for immersed method at $9 \mathrm{am}$. 


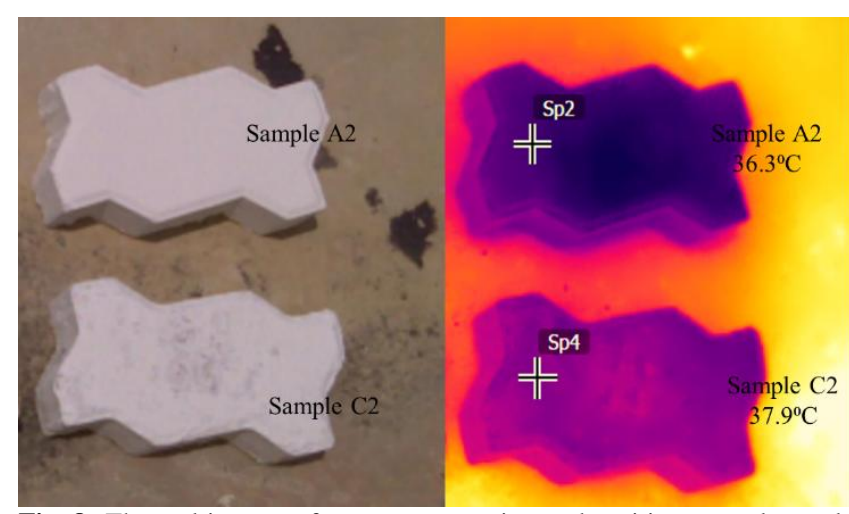

Fig. 8: Thermal images of vege-grout coating and positive control sample for immersed method at $12 \mathrm{pm}$.

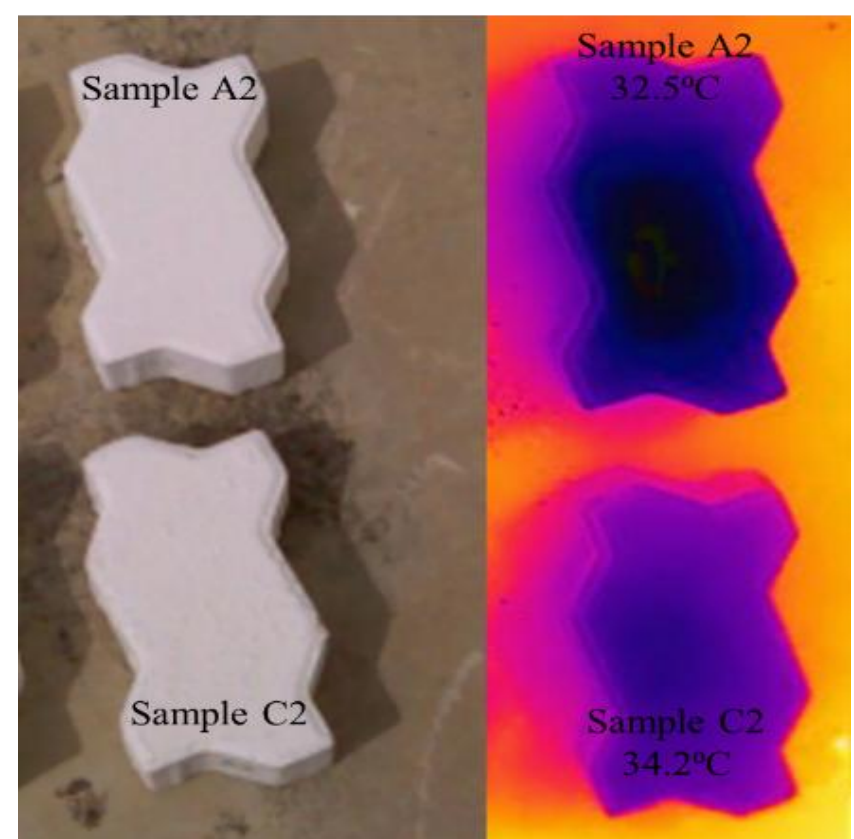

Fig. 9: Thermal images of vege-grout coating and positive control sample for immersed method at $3 \mathrm{pm}$.

Thermal images of samples between VG2S coating (A4) and positive control (C6) of layered method are shown in the Figures 10,11 and $12 \mathrm{As}$ the ambient temperature in the morning is still cool, there was only $0.5^{\circ} \mathrm{C}$ difference in surface temperture between samples and is shown in the Figure 10. This thermal image was taken at $9 \mathrm{am}$. At $12 \mathrm{pm}$ the differences of surface temperature become sligthly bigger that is $0.9^{\circ} \mathrm{C}$ as shown in Figure 11. As for Figure 12, image was taken at $3 \mathrm{pm}$ and its differences of surface temperature is $0.4^{\circ} \mathrm{C}$.

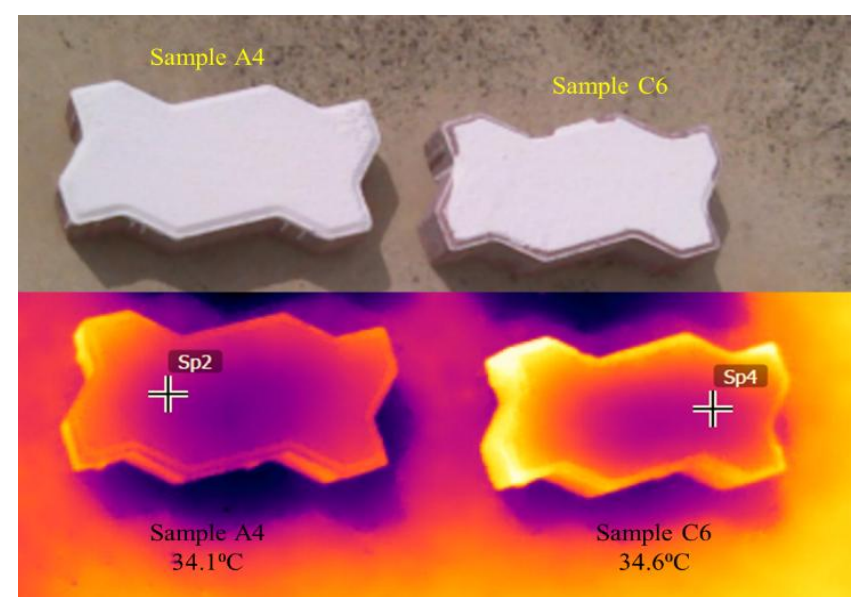

Fig. 10: Thermal images of vege-grout coating and positive control sample for layered method at $9 \mathrm{am}$

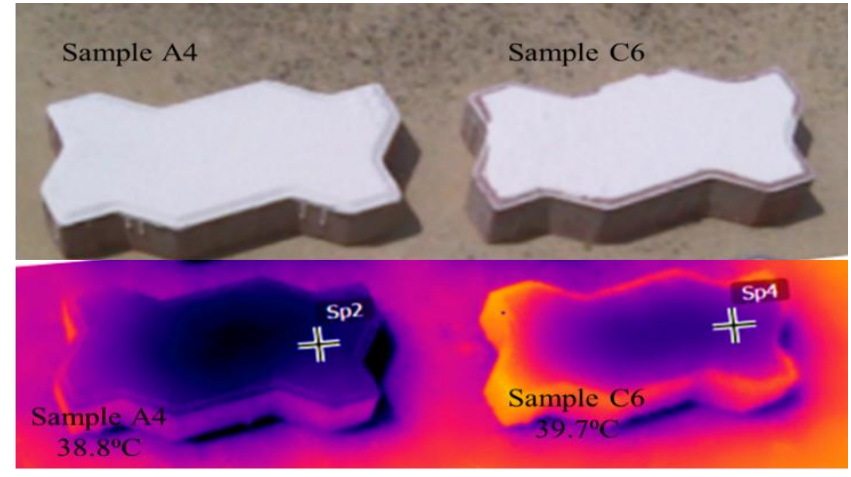

Fig. 11: Thermal images of vege-grout coating and positive control sample for layered method at $12 \mathrm{pm}$.

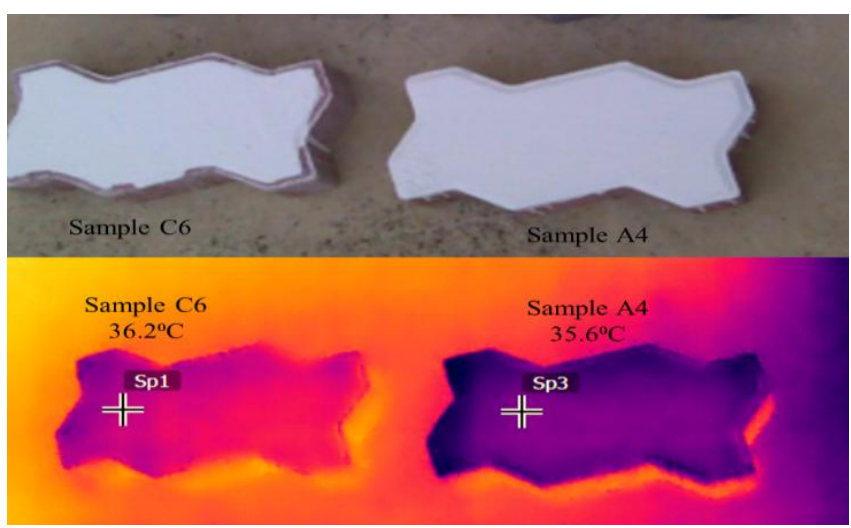

Fig. 12: Thermal images of vege-grout coating and positive control sample for layered method at $3 \mathrm{pm}$.

Samples of VG2S coating of both methods were taken together with negative control in the thermal images as they have the same negative control samples. Their thermal images are shown in Figure 13, 14 and 15 . C3 is the negative control sample while B2 and B4 are VG2S coating sample for immersed and layered method respectively. Figure 13 was taken at 9am show that negative control has the highest surface temperature followed by B2 sample and lastly B4 sample. The differences between C3 sample and B2 sample are $5^{\circ} \mathrm{C}$ and difference between $\mathrm{C} 3$ and $\mathrm{B} 4$ sample are $6^{\circ} \mathrm{C}$. At $12 \mathrm{pm}$, biggest differences in surface temperature were recorded that is between sample $\mathrm{C} 3$ and $\mathrm{B} 4$. The difference is $10.4^{\circ} \mathrm{C}$ while for sample between $\mathrm{C} 3$ and $\mathrm{B} 2$, their differences were also big that is $9.3^{\circ} \mathrm{C}$. Their thermal image is shown in Figure 14. As for Figure 15, it was taken at 3pm. All surface temperature of samples reduces than surface temperature at 12pm. But still, C3 sample has the highest surface temperature then followed by B2 sample then B4 sample. The differences of surface temperature between sample $\mathrm{C} 3$ and $\mathrm{B} 2$ and between sample $\mathrm{C} 3$ and $\mathrm{B} 4$ are $3.5^{\circ} \mathrm{C}$ and $4.1^{\circ} \mathrm{C}$ respectively.

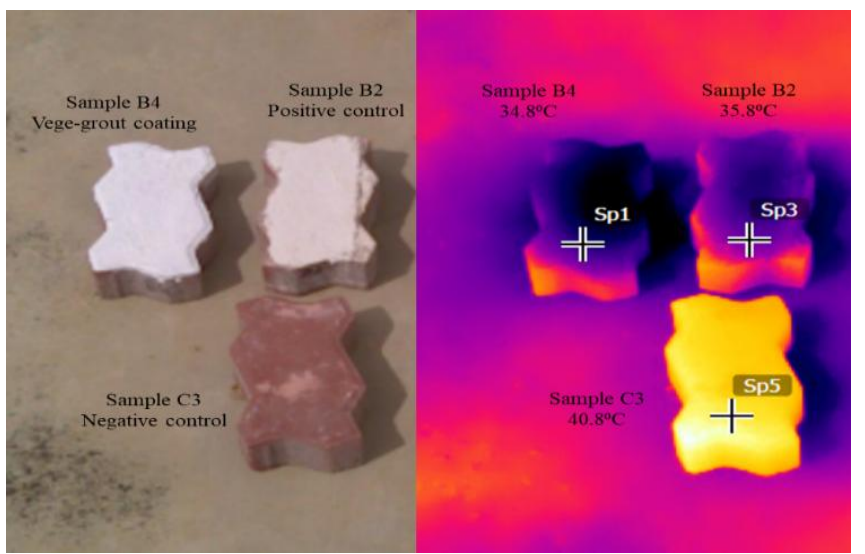

Fig. 13: Thermal image of vege-grout coating, positive control and negative control sample at $9 \mathrm{am}$. 


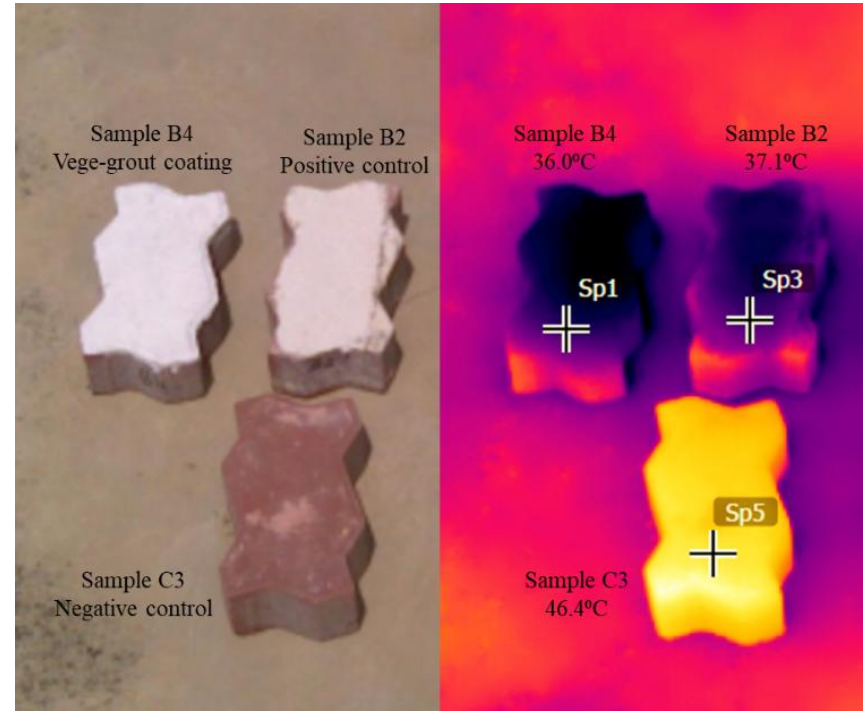

Fig. 14: Thermal image of vege-grout coating, positive control and negative control sample at $12 \mathrm{pm}$.

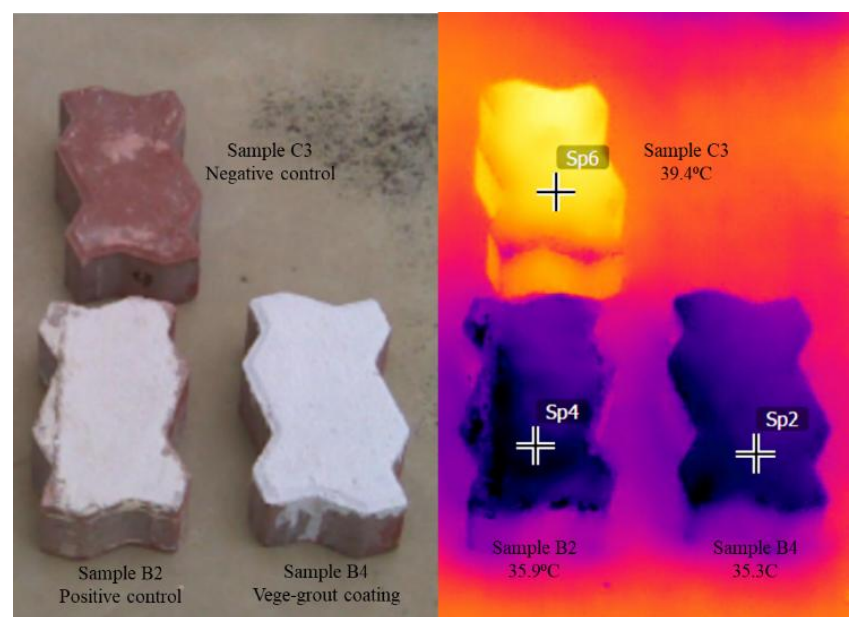

Fig. 15: Thermal image of vege-grout coating, positive control and negative control sample at $3 \mathrm{pm}$.

\subsection{SEM-EDX Analysis}

From the analysis of SEM-EDX, there have been recorded that there was a formation of calcite percipitation or calcium carbonate $(\mathrm{CaCO} 3)$ on the surface of vege-grout coating materials that was induced by ureolytic microorganisms as shown in Figure 16.

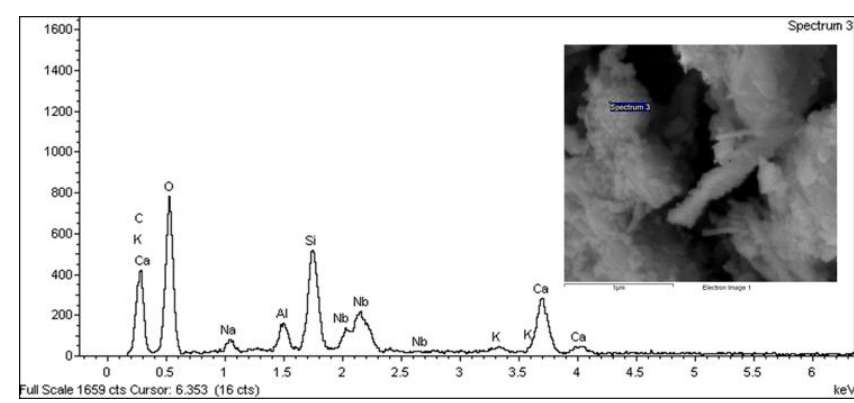

Fig. 16: SEM-EDX analysis showing amount of calcium formation

\section{Conclusion}

Natural coating from mixture of vege-grout (VG2S) with eggshell, white paint made by clay process and urea that are synthesis from ball clay result shows that it can be used as natural coating for reducing surface heat. However, the technique to applied the coating on the surface of red paver is important to ensure the maximum reducing of urban heat. Results shows that the paver using layered method has the lowest surface temperature compared to other samples.

The used of clay and urea from ball clay synthesis in the study shows that the coating material from VG2S can helps the material to reduce the temperature in day time and ensure directly proportional to the ambient temperature.

\section{Acknowledgement}

Authors wish to acknowledge assistance from lecturers, friends and Universiti Tenaga Nasional (UNITEN) for the supports. The authors also would like to extend their gratitude to financial support from UNITEN R\&D under U-TS-RD-17-03 grant.

\section{References}

[1] J. M. Tukiran, J. Ariffin, and A. N. A. Ghani, "Comparison on colored coating for asphalt and concrete pavement based on thermal performance and cooling effect," J. Teknol., vol. 78, no. 5, (2016), pp. $63-70$.

[2] S. L. Harlan and D. M. Ruddell, "Climate change and health in cities: Impacts of heat and air pollution and potential co-benefits from mitigation and adaptation," Curr. Opin. Environ. Sustain, vol. 3, no. 3, (2011), pp. 126-134.

[3] J. S. Golden, "The Built Environment Induced Urban Heat Island Effect in Rapidly Urbanizing Arid Regions - A Sustainable Urban Engineering Complexity," Environ. Sci., vol. 1, no. 4, (2004), pp. 321-349

[4] A. Mater, S. Università, D. I. Bologna, S. Di, and I. E. Architettura, "The role of paved surfaces in the Urban Heat Island phenomenon: assessment of fundamental thermal parameters and Finite Element Analysis for UHI mitigation ,", (2013).

[5] H. Wu, Z. Liu, Y. Yang, and S. Bai, "Characterizing Thermal Impacts of Pavement Materials on Urban Heat Island (UHI) Effect," no. Ictim, (2016), pp. 415-422.

[6] S. Sreedhar and K. P. Biligiri, "Development of pavement temperature predictive models using thermophysical properties to assess urban climates in the built environment," Sustain. Cities Soc. vol. 22, (2016), pp. 78-85.

[7] Y. Qin, "A review on the development of cool pavements to mitigate urban heat island effect," Renew. Sustain. Energy Rev., vol. 52, (2015), pp. 445-459.

[8] C. Efthymiou, M. Santamouris, D. Kolokotsa, and A. Koras, "Development and testing of photovoltaic pavement for heat island mitigation," Sol. Energy, vol. 130, (2016), pp. 148-160.

[9] Y. Qin and J. E. Hiller, "Understanding pavement-surface energy balance and its implications on cool pavement development," Energy Build., vol. 85, (2014), pp. 389-399.

[10] N. Anting et al., "Experimental evaluation of thermal performance of cool pavement material using waste tiles in tropical climate," Energy Build., vol. 142, (2017), pp. 211-219.

[11] N. Anting et al., "Optimizing of near infrared region reflectance of mix-waste tile aggregate as coating material for cool pavement with surface temperature measurement," Energy Build., vol. 158, (2018), pp. $172-180$.

[12] A. Sha, Z. Liu, K. Tang, and P. Li, "Solar heating reflective coating layer (SHRCL) to cool the asphalt pavement surface," Constr. Build. Mater., vol. 139, (2017), pp. 355-364.

[13] Y. Y. Lee, M. S. Halim, E. Aminudin, and N. A. Guntor, "Thermal repellent properties of surface coating using silica," IOP Conf. Ser. Mater. Sci. Eng., vol. 271, no. 1, (2017).

[14] W. Wan and W. Hien, "A study on the effectiveness of heat mitigating pavement coatings in Singapore," J. Heat Isl. Inst. Int., vol. 7, no. 2, (2012), pp. 238-247.

[15] L. van Paassen, Biogrout: Ground Improvement by Microbially Induced Carbonate Precipitation, (2009).

[16] I. N. Z. Baharuddin, R. C. Omar, and Y. Devarajan, "Improvement of engineering properties of liquefied soil using Bio-VegeGrout," IOP Conf. Ser. Earth Environ. Sci., vol. 16, no. 1, (2013).

[17] R. C. Omar, R. Roslan, I. N. Z. Baharuddin, and M. I. M. Hanafiah, "Micaceous Soil Strength and Permeability Improvement Induced by Microbacteria from Vegetable Waste," IOP Conf. Ser. Mater. Sci. Eng., vol. 160, no. 1, (2016). 
[18] H. Canakci, W. Sidik, and I. Halil Kilic, "Effect of bacterial calcium carbonate precipitation on compressibility and shear strength of organic soil," Soils Found., vol. 55, no. 5, (2015), pp. 1211-1221.

[19] D. Mujah, M. A. Shahin, and L. Cheng, "State-of-the-Art Review of Biocementation by Microbially Induced Calcite Precipitation (MICP) for Soil Stabilization," Geomicrobiol. J., vol. 34, no. 6, (2017), pp. 524-537.

[20] K. Wang, Z. Wen, S. Choi, A. Iowa State University, M. T. Center, and R. and I. T. Administration, "Development of an Eco-Friendly, Cost-Effective Biogrout for Concrete Crack Repair," no. September, (2016), p. 59p.

[21] O. Olgun, A. Ö. Yildiz, and Y. Cufadar, "The effects of eggshell and oyster shell supplemental as calcium sources on performance, eggshell quality and mineral excretion in laying hens," Indian J. Anim. Res., vol. 49, no. 2, (2015), pp. 205-209.

[22] J. M. Connolly, B. Jackson, A. P. Rothman, I. Klapper, and R. Gerlach, "Estimation of a biofilm-specific reaction rate: Kinetics of bacterial urea hydrolysis in a biofilm," npj Biofilms Microbiomes, vol. 1, no. July, (2015), pp. 1-8. 